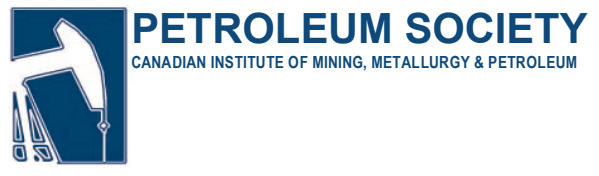

PAPER 2007-116

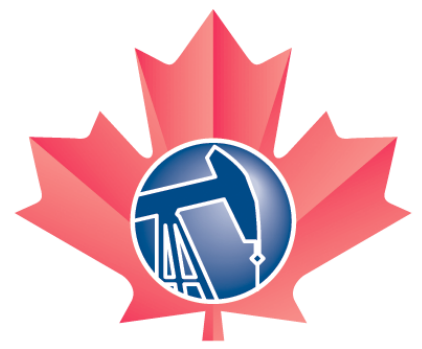

CANADIAN INTERNATIONAL

PETROLEUM CONFERENCE

\title{
Applications of Autonomous Underwater Vehicles in Offshore Petroleum Industry Environmental Effects Monitoring
}

\author{
H. NIU, S. ADAMS, T. HUSAIN, N. BOSE \\ Memorial University of Newfoundland \\ K. LEE \\ Bedford Institute of Oceanography
}

This paper is to be presented at the Petroleum Society's 8th Canadian International Petroleum Conference (58th Annual Technical Meeting), Calgary, Alberta, Canada, June $12-14,2007$. Discussion of this paper is invited and may be presented at the meeting if filed in writing with the technical program chairman prior to the conclusion of the meeting. This paper and any discussion filed will be considered for publication in Petroleum Society journals. Publication rights are reserved. This is a pre-print and subject to correction.

\begin{abstract}
Environmental Effects Monitoring (EEM) is an important tool in assisting Environmental Risk Assessment (ERA). EEM in the offshore petroleum industry has been conducted world wide, but traditional approaches have struggled to keep apace as exploration and production activities move to frontier regions, such as increasingly deeper waters and Arctic regions. This paper proposes the use of autonomous underwater vehicles (AUVs) for environmental monitoring of offshore facilities as a means of improving and expanding the overall monitoring program. The paper provides a review of technical and procedural issues involved in this application of AUV technology, including the current status of offshore oil and gas EEM, a review of available AUVs, and a survey of developments in in-situ sensors
\end{abstract}

\section{Introduction}

Offshore petroleum industry operations affect the marine environment in a variety of ways: high sound levels from seismic surveys that affect marine animals; exposure of marine organisms to drilling mud, produced water discharges, and accidentally spilled oils; and the physical alteration of habitat due to the construction of submarine structures. The potential risks to the environment posed by offshore oil and gas operations support the need for effective Environmental Effects Monitoring (EEM) around the project development areas.

EEM is a central component of environmental protection and management strategies designed to minimize the consequences of anthropogenic activities (GESAMP, 1991). It is a very important tool in assisting Environmental Risk Assessment (ERA) which is seen from many studies that link the EEM and ERA together (Wells, 2000; Smit et al., 2005). EEM is required by regulations governing industry activities in the offshore, and by government agencies in relation to cumulative impact assessment studies (Cott, 2003).

The United States started the use of environmental monitoring programs in 1973. The Mineral Management Services is currently responsible for managing oil and gas activities on the outer continental shelf (OCS). In the early stages of EEM programs, MMS monitored the effects of 
petroleum exploration activities on the George's Bank, Middle Atlantic OCS, and Gulf of Mexico. Early monitoring programs mainly focused on the effects of drilling wastes on benthic communities through a variety of sampling methods, such as camera transects, crab traps, bottom trawls, and box corers. The MMS also has monitored the effects of petroleum development and production activities in the Gulf of Mexico, Santa Maria and Western Santa Barbara Channels off California, and in the Alaska Beaufort Sea. Trace metals and hydrocarbons in the water column, sediments, pore waters, and biological tissues are collected and analyzed. A more detailed description of U.S. EEM programs can be found from Ahlfeld (2005).

In Canada, both government agencies and operators have carried out EEM. For example, Petro-Canada collected sediment samples from 49 stations and water samples from 24 stations in an area located in the vicinity of the Terra Nova oil field during 2000 to 2001. Analyses of samples include hydrocarbon concentration, metal concentration, particle size, and the presence of sulphur, sulphide, and ammonia (DeBlois et al., 2005). Fisheries and Oceans Canada also conducts annual EEM missions at the Hibernia, Terra Nova, and The baud fields off the east coast of Canada. Both sediment and water samples are collected and the biodiversity of benthic organisms are studied using underwater photography.

EEM plans typically require regular collection of biological, chemical and physical data from predetermined locations. This has been traditionally implemented by deploying water sample collection instruments (such as Rosette bottles) or towing deepwater sensors from a vessel. However, oil and gas activities have progressed toward deeper and colder waters world-wide and this trend raises greater challenges for EEM. Conducting EEMs in these sometimes harsh, remote and fragile environments is very time consuming and expensive. As a result, the data collected are often incomplete and provide very limited information. It is noted that increasing water depth also increases the level of sampling error due to the drift of surface vessel platforms and prolonged sampling times. Traditional monitoring techniques can not account for the dynamics of the ocean environment. As a result, traditional methods used for EEM require a radical change in deeper water and ice covered fields. New and innovative means of acquiring EEM information to specified accuracy and precision is critical.

One solution is the use of a new generation of autonomous oceanographic platform -Autonomous Underwater Vehicles (AUVs) - that is capable of tracking water masses, recording chemical/physical/biological properties, and transmitting data without tether to either the seafloor or a vessel. AUVs are able to provide a detailed $4 \mathrm{D}$ view of the dynamic ocean.

In the following sections, an introduction of AUV will be given first followed by a section of their applications in environmental monitoring. The advantages of AUVs will then be described and the sensors needed to fulfill the EEM missions will be summarized.

\section{Autonomous Underwater Vehicles (AUV)}

Autonomous Underwater Vehicles (AUVs) have been under development since late 1950's (Alt, 2003). To date, more than 66 AUVs have been developed in 12 different countries and AUVs have now reached the beginning of commercial acceptance (Wernli, 2000).

AUVs are self propelled underwater robotic devices, controlled and piloted by on board computer. Typically, when on surface, an AUV is normally navigated by a differentialGlobal Positioning System (DGPS) which gives the AUV highly precise navigation capability. When submerged, the position of an AUV is estimated by measuring its relative speeds over the current or seabed via an Acoustic Doppler Current Profiler (ADCP). For more precise navigation, an inertial navigation unit is used with positioning from a sonar system (long baseline or ultra short baseline). A downward ADCP can also be used to measure the AUV's altitude off the seabed and a forward looking echo sounder can help to prevent collisions.

AUVs are manoeuvrable in three dimensions and this enables them to follow a pre-programmed trajectory precisely. One of the best features of an AUV is the ability to carry a wide range of payloads or sensors. As AUVs move through the water column, the sensors conduct both spatial and time series measurements.

Compared with traditional ship-based data collection methods, an AUV can obtain much more information in a relatively short time. It has potential to do so cost effectively. An analysis by C\&C Technologies showed that the total cost of a deepwater survey could be cut from $\$ 770 \mathrm{k}$ using a deeptowed system to $\$ 291 \mathrm{k}$ using an AUV (Wernli, 2000). Unlike Remote Operated Vehicles (ROVs) that require a dedicated ship and human operators at all times, AUVs are self-sufficient, once launched they can return to base autonomously.

Figure 1 shows an AUV in a data collection mission.

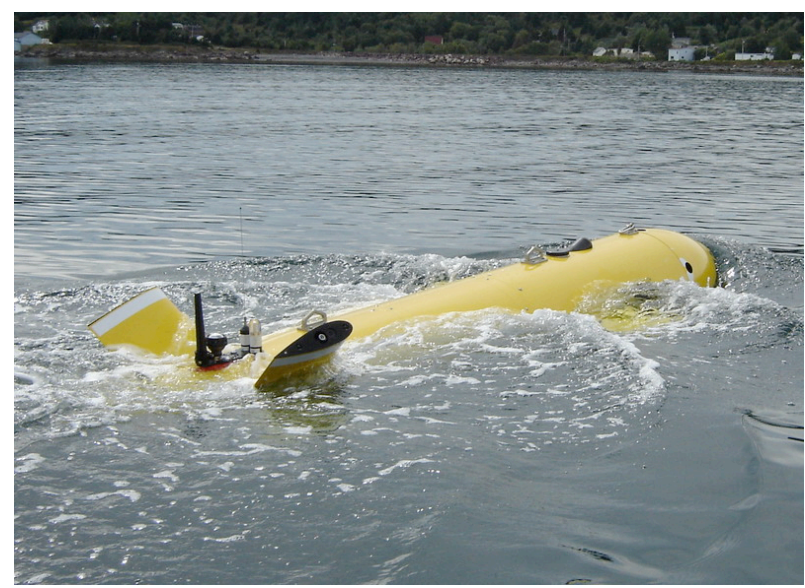

Figure 1. MUN Explorer AUV during a mission

\section{Applications of AUVs in Environmental Monitoring}

The commercial usage of AUVs has been gaining strength in the areas of seabed mapping and oceanographic measurements due to the AUV's ability to provide high-quality, highresolution data compared to ship-based collection (Griffiths, 1997; Alt, 2003). The recent development of in-situ environmental sensors and their integration gives AUVs great potential in performing offshore oil and gas EEM missions; however, very limited work has been conducted in this field.

Not all AUVs are capable of conducting all types of environmental monitoring missions effectively. Many AUVs have been designed for combinations of low-cost, light weight and operations over a confined area (Griffiths, 1997). As a result, these AUVs either have a limited endurance, payload space, depth capability or require continuous communication with a mother control console. Griffiths et al. (1998) have indicated that an AUV must have the following features:

- Have a range capability well in excess of $50 \mathrm{~km}$;

- Be able to carry a sensor payload for the purpose of multidiscipline data gathering; 
- Be reliable, robust, and affordable in terms of capital cost and running expenses.

In this section, five different types of AUVs will be described briefly to show the capability of using AUVs to perform environmental monitoring missions.

\section{REMUS}

The Remote Environmental Monitoring UnitS (REMUS) is a low cost, light weight vehicle specially designed for coastal water monitoring with a maximum depth of $200 \mathrm{~m}$. The REMUS is $1.5 \mathrm{~m}$ long and $20 \mathrm{~cm}$ in diameter. Its dry mass is $30 \mathrm{~kg}$ and its maximum and best energy efficient speeds are 2.05 and $1.02 \mathrm{~m} / \mathrm{s}$, respectively. At $1.02 \mathrm{~m} / \mathrm{s}$, the REMUS can travel for over 20 hours and over $70 \mathrm{~km}$.

The REMUS AUV has been widely used to detect and map chemical plumes (Fletcher, 2001; Ramos et al., 2002; Farrell et al., 2005). In the Fletcher (2001) study, the REMUS carried a Rhodamine fluorometer which was used to map Rhodamine plumes at two different sites. The study areas were $400 \mathrm{~m} \times 100 \mathrm{~m}$, and $1000 \mathrm{~m} \times 800 \mathrm{~m}$ respectively. Different sampling strategies were used and data were successfully collected at depths as low as $1.5 \mathrm{~m}$ above the bottom. Ramos et al. (2002) reported an AUV mission for the Averio sea outfall using temperature and salinity as tracers. A survey area of $100 \mathrm{~m} \times 200 \mathrm{~m}$ and water depth range from 2 to $12 \mathrm{~m}$ were studied. The area was divided into six vertical and horizontal sections and surveyed by the AUV. The data obtained were sufficient to plot a $3 \mathrm{D}$ contour map of the water column. Unlike the two studies described above in which the AUV followed predefined trajectories, the mission by Farrell et al. (2005) demonstrated that the REMUS is able to find a chemical plume and trace the plume to its source.

\section{ARCS}

The ARCS is an AUV developed by International Submarine Engineering Limited (ISE). The ARCS is $6.4 \mathrm{~m}$ long, $68.6 \mathrm{~cm}$ in diameter. It has a range of $36 \mathrm{~km}$ to $235 \mathrm{~km}$ depending on the type of battery pack used. The maximum depth is $300 \mathrm{~m}$. The speed of ARCS is up to $2.8 \mathrm{~m} / \mathrm{s}$.

The ARCS has been used by Pennell et al. (2003) to measure a chemical (Dimethyl sulphide) plume using a Conductivity Temperature Depth (CTD) sensor and In-Spectr underwater mass spectrometer. The AUV was able to successfully detect the presence of a Dimethyl sulphide plume in an area of about $600 \mathrm{~m} \times 600 \mathrm{~m}$ as shown in Figure 2. Although the mission was to detect the Dimethyl sulphide, the ARCS was also able to detect the presence of Toluene in the mission.

\section{MUN Explorer AUV}

Memorial University of Newfoundland has recently acquired a new Explorer class AUV built by International Submarine Engineering Ltd. The AUV is designed as a $4.5 \mathrm{~m}$ ocean-going instrumentation platform with a $3,000 \mathrm{~m}$ depth capability. The strength of the MUN Explorer AUV is its ability to carry $150 \mathrm{~kg}$ of scientific payload (instruments), with a power requirement in the hundreds of Watts, on missions of up to 12 hours duration or $100 \mathrm{~km}$. The mission length drops as power requirement increases. The MUN Explorer is designed such that the whole of the fore end is available for the carriage of different sensor instruments for different types of research missions. Apart from the pressure hull which houses the batteries, control hardware, and navigation systems, the AUV is freely flooded. The fore section casing consists of a relatively low cost fibreglass shell. For complicated instrumentation outfits, the instruments can be installed in their own dedicated instrumentation section shell piece. Different users can be provided with an instrumentation section shell piece in order to outfit their instruments, thus making efficient use of the AUV time and availability for missions.

The MUN Explorer has recently conducted a plume mapping mission in a shallow bay at Holyrood, off the east coast of Canada. The mission was to measure a freshwater plume with Rhodamine dye discharge $3 \mathrm{~m}$ below sea surface. The AUV was outfitted with a Cyclops-7 fluorometer and a CTD sensor and was able to measure successfully the presence of Rhodamine in an area of $200 \mathrm{~m} \times 300 \mathrm{~m}$ at different depths ranging from 0.4 to $1.5 \mathrm{~m}$. An example of the data measured is shown in Figure 3

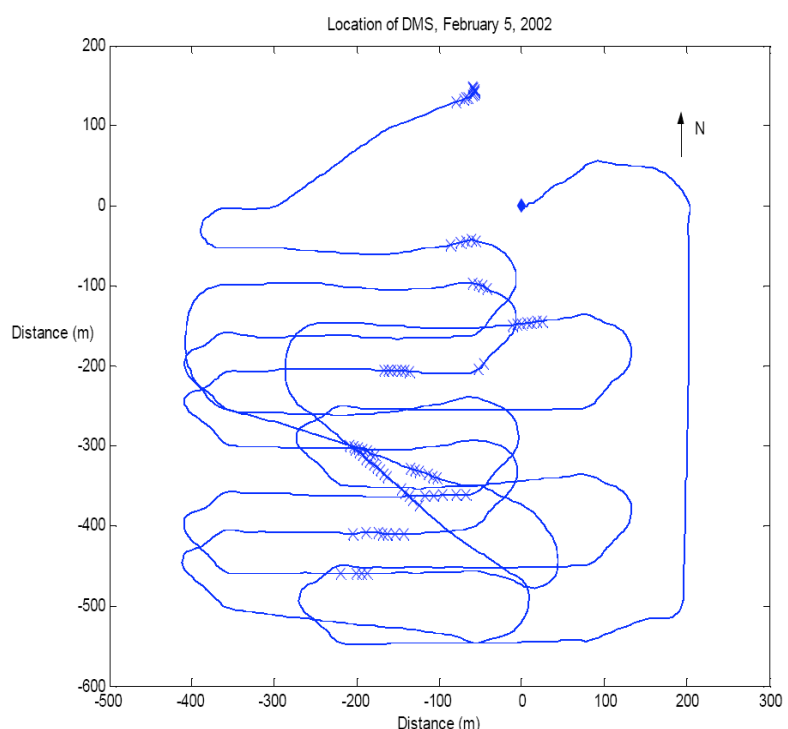

Figure 2. Location of Dimethyl sulphide plume (source: Pennell 2003).

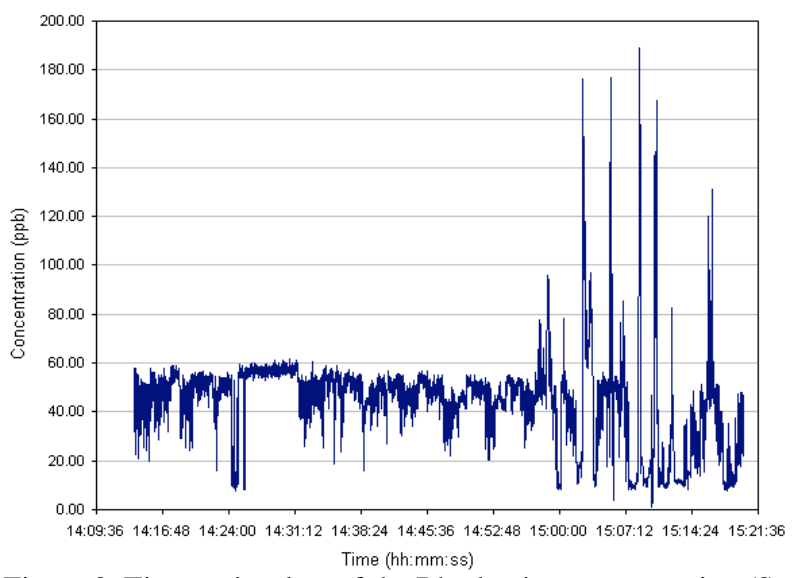

Figure 3. Time series data of the Rhodamine concentration (Sep 7, 2006).

With the initial success of the plume mapping mission, another mission to map a sewage outfall at Conception Bay South (off the east coast of Canada) is being prepared. In addition to the Rhodamine fluorometer and CTD, more sensors such as Dissolved Oxygen, Chlorophyll, and Turbidity meter will also be used.

\section{AUTOSUB}

The AUTOSUB program is operated by Southampton Oceanography Centre in Southampton, U.K. The overall focus of the programs is on using AUVs for marine science. 
AUTOSUB is a large vehicle, $6.8 \mathrm{~m}$ long and $0.9 \mathrm{~m}$ in diameter with a payload capability of $100 \mathrm{~kg}$ in water. The program has been successful in testing the boundaries of the autonomous nature of the vehicle in that a major focus in recent years has been under ice exploration with missions in near Greenland and the Antarctic. AUTOSUB has conducted an estimated 270 missions with the longest being $292 \mathrm{~km}$ or 50 hours. A wide variety of sensors have been integrated into the AUTOSUB since its initial missions in the nineties (Griffiths et al., 2001). These have included physical (CTD and ADCP) and chemical (nitrate and manganese) sensors (Griffiths et al., 2001; Statham et al., 2005). Acoustic measurements have included fisheries echo sounders, side scan sonars and multi-beam sonars which have led to cutting edge research in their given fields (Fernandes et al., 2000; Wadhams et al., 2006).

With this type of range and capability to provide for extensive science missions, AUTOSUB and other vehicles like it are suited to provide unprecedented access to areas otherwise inaccessible using traditional methods.

\section{TANTAN}

The TANTAN is an AUV designed by the University of Tokyo for freshwater survey. The size of TANTAN is $2.0 \mathrm{~m}(\mathrm{~L})$ $\times 0.75 \mathrm{~m}(\mathrm{~W}) \times 0.75 \mathrm{~m}(\mathrm{H})$. Its maximum depth is $150 \mathrm{~m}$ and maximum speed is $1.02 \mathrm{~m} / \mathrm{s}$ (Kumagai et al., 2000).

Unlike the previously described studies, TANTAN is equipped with a submersible microscope digital camera. This enables TANTAN to detect plankton and other water-born objects. The species type and sizes can be determined from the images using pattern recognition technique. The ability to automatically track a moving object is currently being developed.

\section{Using AUV in Offshore Petroleum Industry EEM}

To date, there has been no application of an AUV in the field of offshore oil and gas environmental effects monitoring. The review in previous section demonstrated that AUVs have the capability to conduct offshore EEM missions.

For offshore oil and gas EEM, contaminants and marine organisms from both sediments and water columns need to be studied. The real time analysis of contaminants and organisms in sediment is impractical for current AUV technology, so the major application of AUV in offshore EEM is to conduct water column measurements for contaminants and marine species. This means the AUV technology at its current stage can only be an enhancement, rather than a replacement, of current EEM technology.

To collect EEM information from the water column, an AUV needs to be equipped with appropriate sensors. A detailed list of some candidate physical and chemical in-situ sensors is given by Earle (2003). The current capability of available candidate sensors is listed in Table 1.

Salinity of produced water many range from a few parts per thousand (ppt) up to $300 \mathrm{ppt}$ and it may be used as a conservative tracer. This has been proven by a previous study by Woodall et al. (2001). CTD sensors have been well developed and can be operated in water as deep as $6000 \mathrm{~m}$. When the salinity difference is insignificant, other trace elements such as hydrocarbon and metals can be used. Hydrocarbons, either as a surface film, emulsion, or in the dissolved phase can be detected and measured using fluorescence with excitation wave lengths around $360 \mathrm{~nm}$ and emission wave lengths from $410 \mathrm{~nm}$ to $600 \mathrm{~nm}$ (Griffiths, 2005).
There are at least three sensors of this type which can be used with AUVs to detect hydrocarbons: Spill-Sentry, UV Aquatracka, and SAFire. The standard depths for these sensors are around $500 \mathrm{~m}$ to $600 \mathrm{~m}$ but the $6000 \mathrm{~m}$ version of UV Aquatracka is available for deep water measurements. The InSpectr, an underwater mass spectrometer, can also be used to determine chemicals such as hydrocarbons with atomic mass unit values up to 200. Produced waters may contain various types of metal such as $\mathrm{Fe}, \mathrm{Mn}, \mathrm{Al}, \mathrm{Cu}, \mathrm{Cr}, \mathrm{Pb}, \mathrm{Cd}$ etc. The InSpectr can also be used to determine these metals but it is limited to water depths less than $200 \mathrm{~m}$. The VIP system can be used to measure six types of metals (as listed in Table 1) in waters up to $500 \mathrm{~m}$ deep. To the authors' best knowledge, still there are no sensors available for detection of metals in deeper waters. Nutrients are also very important to study the effects of produced waters. The nutrients may be monitored using a SubChemPak sensor in waters less than $200 \mathrm{~m}$. Information on plankton can be obtained by using microscope cameras with pattern recognition technique. Biodiversity information, for example the presence of commercial species (such as crab), can be acquired using onboard digital cameras.

Table 1 Specifications of candidate sensors

\begin{tabular}{|c|c|c|c|c|}
\hline Parameters & Range & Dimension & $\begin{array}{l}\text { Depth } \\
\text { (m) }\end{array}$ & Sensor \\
\hline Temperature & $\begin{array}{c}-2{ }^{\circ} \mathrm{C} \sim 55 \\
{ }^{\circ} \mathrm{C}\end{array}$ & $\begin{array}{c}40 \mathrm{~cm} \times \\
6 \mathrm{~cm}\end{array}$ & $\begin{array}{l}\text { Up to } \\
6000\end{array}$ & $\begin{array}{l}\text { SD } 204 \text { Mini } \\
\text { CTD }\end{array}$ \\
\hline Salinity & $0 \sim 60 \mathrm{ppt}$ & $\begin{array}{c}40 \mathrm{~cm} \times \\
6 \mathrm{~cm}\end{array}$ & $\begin{array}{l}\text { Up to } \\
6000\end{array}$ & $\begin{array}{l}\text { SD } 204 \text { Mini } \\
\text { CTD }\end{array}$ \\
\hline Turbidity & $\begin{array}{c}0.01 \sim 800 \\
\text { NTU }\end{array}$ & $\begin{array}{l}6.3 \mathrm{~cm} \times \\
12.7 \mathrm{~cm}\end{array}$ & 6000 & $\begin{array}{c}\text { ECO-FL- } \\
\text { NTU }\end{array}$ \\
\hline $\begin{array}{l}\text { Dissolve } \\
\text { Oxygen }\end{array}$ & $\begin{array}{c}0 \text { to } 15 \\
\mathrm{mg} / \mathrm{l}\end{array}$ & $\begin{array}{l}5 \mathrm{~cm} \times \\
20 \mathrm{~cm}\end{array}$ & 1500 & Micro CTD \\
\hline Chlorophyll & $\begin{array}{c}0.01 \sim 50 \\
\mathrm{ppb}\end{array}$ & $\begin{array}{l}6.3 \mathrm{~cm} \times \\
12.7 \mathrm{~cm}\end{array}$ & 6000 & $\begin{array}{l}\text { ECO-FL- } \\
\text { NTU }\end{array}$ \\
\hline Nutrients & $\begin{array}{l}\text { nanomolar } \\
\text { to } \\
\text { micromolar }\end{array}$ & $\begin{array}{c}63.5 \mathrm{~cm} \times \\
12.7 \mathrm{~cm}\end{array}$ & 200 & SubChemPak \\
\hline $\begin{array}{l}\text { Particulate } \\
\text { Matter }\end{array}$ & No data & $\begin{array}{l}6.3 \mathrm{~cm} \times \\
12.7 \mathrm{~cm}\end{array}$ & 600 & ECO-VSF \\
\hline Hydrocarbons & $\begin{array}{c}0.001 \sim 10 \\
\mu \mathrm{g} / \mathrm{L}\end{array}$ & $\begin{array}{c}40.6 \mathrm{~cm} \times \\
8.9 \mathrm{~cm}\end{array}$ & $\begin{array}{l}600 \\
\text { or } \\
6000\end{array}$ & $\begin{array}{c}\text { UV } \\
\text { Aqua }^{\text {Tracka }}\end{array}$ \\
\hline Hydrocarbons & $\begin{array}{l}\text { five } \\
\text { microns } \\
\text { sheen }\end{array}$ & varies & $\begin{array}{l}\text { No } \\
\text { data }\end{array}$ & Spill-sentry \\
\hline $\begin{array}{l}\text { Hydrocarbons } \\
\text { and others }\end{array}$ & No data & $\begin{array}{l}40.6 \mathrm{~cm} \times \\
8.9 \mathrm{~cm}\end{array}$ & 500 & SAFire \\
\hline $\begin{array}{l}\text { VOCs, } \\
\text { Dissolved } \\
\text { Gases, and } \\
\text { other } \\
\text { chemicals }\end{array}$ & $\begin{array}{l}\text { normally } \\
\text { ppb level }\end{array}$ & $\begin{array}{c}120 \mathrm{~cm} \times \\
19 \mathrm{~cm}\end{array}$ & 200 & In-Spectr \\
\hline$(0 \sim 200 \mathrm{~m} / \mathrm{z})$ & & & & \\
\hline $\begin{array}{l}\mathrm{Cu}^{2+}, \mathrm{Pb}^{2+}, \\
\mathrm{Cd}^{2+}, \mathrm{Zn}^{2+} \\
\mathrm{Mn}^{2+}, \mathrm{Fe}^{2+}\end{array}$ & $\begin{array}{c}40 \sim \\
1000 \mathrm{ppt}\end{array}$ & $\begin{array}{l}10 \mathrm{~cm} \text { in } \\
\text { diameter }\end{array}$ & 500 & VIP system \\
\hline
\end{tabular}

For the investigation of long term effects of drilling muds, sediment samples have to be analyzed. Simple grabs and corers are currently being used for sample collection. The AUVs are incapable of doing this task at the current state of technology. The study of dispersion of drilling muds during exploration and development stage is also very important, because this affects 
the extent of drilling mud sediment on seabed. Furthermore, the re-suspension of drilling mud into water column from sea bottom is another important mechanism because this increases the likelihood of pollutants intake by marine organisms. Therefore, it is very important to study the particle dynamics. An AUV equipped with a backscattering sensor, such as the ECO-VSF, can be used to study the size distribution and concentration of drilling mud particles in water column and at depths close to bottom. The analysis is automatic and real time which reduces the possible change of distribution due to flocculation during sample collection process.

For oil spill problems, the composition of oil and the thickness and extent of oil sheen need to be known for true assessment of the spilled oil (Griffith, 2005). The sensors described previously for hydrocarbon detection in produced water can also been used for oil spill characterization purposes.

It can be seen from Table 1, the maximum water depth for currently available sensors such as nutrient, particulate matter, and some metals are limited to $500 \mathrm{~m}$ to $600 \mathrm{~m}$. This limits the possibility of using AUV to collect these types of information in deeper waters. Development of deep water sensors for these parameters is therefore critical.

\section{Conclusion}

The search of offshore oil and gas has taken the petroleum industry into more harsh and remote environments. Current offshore EEM approaches require a radical change to keep a pace with this trend.

The development of the AUV is a promising technology, which has been demonstrated as an effective environmental monitoring tool. With the recent development of in-situ sensors, AUVs have great potential in conducting offshore environmental monitoring missions.

The AUV can only serve as an enhancement rather than a replacement of current approach due to the availability of certain sensors and its lack of ability to collect sediment samples.

\section{Acknowledgements}

The financial support from Petroleum Research Atlantic Canada (PRAC)/NSERC Collaborative Research and Development (CRD) Grants Program is highly appreciated.

\section{REFERENCES}

1. AHLFELD, T.E., Offshore Oil and Gas Environmental Effects Monitoring Investigations Conducted by the U.S. Minerals Management Service; Offshore Environmental effects Monitoring: Approaches and Technologies, Armsworthy, S.L., Cranford, P. J., and K. Lee (eds), Battelle Press, pp.415-431, 2005.

2. ALT, C. V., Autonomous Underwater Vehicles; ALPS: Autonomous and Lagrangian Platforms and Sensors Workshop, La Jolla, California, U.S, 31 March- 2 April, 2003.

3. COTT, K., A Community-based Effects Monitoring in the Beaufort Sea; Offshore Environmental effects Monitoring: Approaches and Technologies, Armsworthy, S.L., Cranford, P. J., and K. Lee (eds), Battelle Press, pp.55-69, 2005.

4. DEBLOIS, E. M., LEEDER, C., PENNEY, K.C., MURDOCH, M., PAINE, M.D., POWER, F.,
WILLIAMS, U.P., Terra Nova Environmental Effects Monitoring Program: From Environmental Impact Statement Onward; Offshore Environmental effects Monitoring: Approaches and Technologies, Armsworthy, S.L., Cranford, P. J., and K. Lee (eds), Battelle Press, pp.475-492, 2005.

5. Earl, J., Candidate Sensors for Autonomous Underwater Vehicles; OERC Report, Faculty of Engineering \& applied Science, Memorial University of Newfoundland, St. John's, NL, Canada, 2003.

6. FARRELL, J. A., PANG, S., and LI, W., Chemical Plume Tracing Via an Autonomous Underwater Vehicle; IEEE Journal of Oceanic Engineering, Vol. 30, No. 2, pp.428-442, 2005.

7. FLETCHER, B., Chemical Plume Mapping with an Autonomous Underwater Vehicle; Proceedings of the MTS/IEEE Oceans 2001 Conference, Honolulu, U.S., 58 November, 2001.

8. FERNANDES, P.G., BRIERLEY, A. S., SIMMINODS, E. J., MILLARD, N. W., MCPHAIL, S.D., ARMSTRONG, F., STEVENSON, P., and SQUIRES, M., Fish Do Not Avoid Survey Vessels; Nature, Vol. 404, pp.35-36, 2000.

9. GESAMP (Joint Group of Experts on the Scientific Aspects of Marine Environmental Protection), Global Strategies for Marine Environmental Protection; Reports and Studies, No. 45, 34pp, 1991.

10. GRIFFITHS, G., Review of Oceanographic Equipment and Sensors for the Detection and Measurement of Pollutants; Research \& Consultancy Report No. 99, Southampton Oceanography Centre, University of Southampton, U.K., 2005.

11. GRIFFITHS, G., Ocean science applications for Autonomous Underwater Vehicles - the Workplan for AUTOSUB-1 for 1997-2000 and Beyond; Unmanned Underwater Vehicle Showcase, Southampton, U.K., September 1997.

12. GRIFFITHS, G., MILLARD, N.W., MCPHAIL, S.D., STECENSON, P., PERRET, J.R., PEBODY, M., WEBB, A.T., and MELDRUM, D.T., Towards Environmental Monitoring with the AUTOSUB Autonomous Underwater Vehicle; Proceedings of the IEEE Underwater Technology '98 Conference, Tokyo, Japan, April, 1998.

13. GRIFFITHS, G., MILLARD, N.W., MCPHAIL, S.D., STECENSON, P., BRIERLEY, A. S., FERNANDES, P G, SMEED, D. A., STANSFIELD, K., THORPE, S. A., OSBORN, T., FARMER, D. M., STATHAM, P. J., CONNELLY D. P., GERMAN, C.R., CUNNINGHAM, A., and BURKILL, P., Standard and Special: Sensors used During the Autosub Science Missions Programme; Symposium on Sensors and Autonomous Underwater Vehicles, Miami Beach, Florida, U.S., 4 April, 2001.

14. KUMAGAI, M., URA, T., KURODA, Y., WALKER, R., New AUV Designed for Lake Environment Monitoring; Proceedings of Underwater Technology 2000, Tokyo, Japan, 23-26 May, 2000.

15. PENNELL, V., VEITCH, B., HAWBOLDT, K., HUSAIN, T., BOSE, N., EATON, G., and FERGUSON, J., Use of Autonomous Underwater Vehicle for Environmental Effect Monitoring; 13th International Symposium on Unmanned Untethered Submersible Technology, Durham, NH, U.S., 24-27 August, 2003.

16. RAMOS, P., NEVES, M.V., PEREIRA, F. L., QUINTANEIRO, I., Mapping the Aveiro Sea Outfall Plume: Sampling Strategy for an Autonomous Underwater Vehicle; 2nd International Conference on 
Marine Wastewater Discharges, Istanbul, Turkey, 16-20 September, 2002.

17. SMIT, M. G. D., VAN DALFSEN, J.A., and KARMAN, C. C. Linking the Different Worlds of Environmental Risk Assessment and Environmental Effect Monitoring; Offshore Environmental effects Monitoring: Approaches and Technologies, Armsworthy, S.L., Cranford, P. J., and K. Lee (eds), Battelle Press, pp.25-53, 2005.

18. STATHAM, P. J., CONNELLY, D. P., GERMAN, C. R., BRAND, T., OVERNELL, J. O., BULUKIN, E., MILLARD, N., MCPHAIL, S., PEBODY, M., PERRETT, J., SQUIRES, M., STEVENSON, P. and WEBB, A., Spatially Complex Distribution of Dissolved Manganese in a Fjord as Revealed by High-Resolution in Situ Sensing Using the Autonomous Underwater Vehicle Autosub; Environmental Science and Technology, Vol. 39, No. 24, pp.9440 - 9445, 2005.

19. WADHAMS, P., WILKSON, J. P., and MCPHAIL, S. D., A New View of the Underside of Arctic Sea Ice; Geophysical Research Letters, Vol. 33, 2006.

20. WELLS, P.G., Workshop Summary and Reflections; Understanding the Environmental effects of Offshore Hydrocarbon Development, Canadian Technical report of Fisheries and Aquatic Science 2311, pp.76-82, 2000.

21. WERNLI, R.L., AUV Commercialization - Who's Leading the Pack?; Proceedings of Oceans 2000 MTS/IEEE Conference and Exhibition, Providence, Rhode Island, Vol. 1, pp. 391-395, September 11-14, 2000 . 